\title{
The medical market around 1915
}

\author{
THE COLONIAL POLICY
}

Changes in the colonial policy had consequences for the medical market in the Indies. Revision of the Constitution in 1848 granted Parliament greater influence. The Cultivation System was increasingly subject to discussion; better connections to the colony meant that negative reports reached the Netherlands faster than before. ${ }^{1}$ The liberal MP W.R. van Hoëvell, an important critic of the colonial policy, heard the latest developments in the Indies from familiar names like W. Bosch (Borgers 1941:131). During the discussion in Parliament in 1854 of the Government Regulations - actually the constitution for the Indies - Van Hoëvell strongly criticized the corvée labour duties. The government decided not to expand the Cultivation System further. The colony then faded into the background until around 1860 when the discussion flared up again. During the debate the Batig Slot was not questioned, not even by the liberals who were against the corvée duties in the Cultivation System. They argued in favour of private companies that would be better for the natives. The conservatives swore that private companies would exploit the population and mean the end of the Batig Slot (Joop de Jong 2000:272-7).

While the Cultivation System was being dismantled, the number of private entrepreneurs rose. In 1870 the economic course changed. The Agrarian Law allowed private Western agricultural companies to rent land from natives or lease waste land for a long term from the government. It was not possible to buy land. The Sugar Law from the same year decreed that the government would slowly withdraw from sugar

\footnotetext{
1 From 1840 the overland route; later, in 1856, the introduction of the telegraph and in 1869 the opening of the Suez Canal.
} 
cultivation before 1891; the government retained control over its coffee plantations until 1915. Many private economic activities moved to the Outer Islands. On Sumatra and Kalimantan tobacco and rubber plantations, tin and coal mines and oil extraction were started. New agricultural companies in the Outer Islands, especially on the east coast of Sumatra, rapidly overtook the old plantations on Java. Of the three most important export products (rubber, oil and sugar), only sugar was still exported mainly from Java.

\section{CHANGES IN THE GIVIL MEDICAL SERVICE}

The dismantling of the Cultivation System affected the tasks of the civil servants: from plantation supervisors they became administrators (Van den Doel 1996:148). With the revision of the organization of the European civil service in 1866, the important position of director of Cultivation vanished. Four new departments were created in its stead. For this study the Department of Education, Religion and Industry is important. The scope of activity of this department reflects its striving to view the colony not just as a region to be exploited, but as a country with a population that needed looking after. The Civil Medical Service was one of the sectors of this department. The Civil and the Military Medical Service were still run by one head, but came under the Department of War (for the military version) and under the Department of Education, Religion and Industry (for the civil version). In this period the director of the relevant department took the lead more and more when determining civil health policy, resulting in the head of the Medical Service having increasingly less influence.

The outcome of the Military and the Civil Medical Service being one organization was growing tension. Proposals to partition them encountered financial objections (KV 1891:130). Also, the head of the Medical Service and the health officers objected. The head would lose the additional subsidy for his double posting, and the health officers would no longer be considered for desirable positions like those in the insane asylums, the Pasteur Institute, the dokter djawa school and the medical laboratory in Jakarta. Around 1900 all these posts, even that of Civil Medical Service inspector, were filled by health officers (Kohlbrugge 1909:395-6).

In May 1906 the board of the Bond van Geneesheeren in Neder- 
landsch-Indië requested the governor-general to put an end to this unsatisfactory situation. ${ }^{2}$ In the same year the government appointed the Commissie tot Voorbereiding eener Reorganisatie van den Burgerlijken Geneeskundigen Dienst (Commission charged with a reorganisation of the Civil Medical Service). ${ }^{3}$ Its composition was criticized: the military element was overrepresented, resulting in the Commission being out of touch with the native society. ${ }^{4}$ In June 1908 the Commission issued a detailed report that formed the foundation for the independent Civil Medical Service in 1911..$^{5}$ The new organization focussed more and more on preventative and hygienic measures (Sciortino 1996:42). As a consequence, they assigned the native doctors two functions: treating the sick and promoting hygiene. For the first function the doctor had to treat the patients at home, give their families instructions about the nursing care, and support parents raising children. A new aspect was that he was expected 'to battle ceaselessly against the charlatanism practised here by dukun'. At the same time he must collect as much data as possible about the work of the dukun and publish it in due course. Supervision of the dukun bayi was desperately needed, as their actions led to many deaths among women in labour and babies. He also had to collect insects and other material for the tropical medicine scientists and contribute to science himself: 'You as children of this country must not fall behind your European colleagues in researching the numerous, still unknown and inexplicable cases of disease'. In his second function, hygienist, he had to ensure the cooperation of the native administrators and point out 'everywhere and repeatedly' to the population the negative consequences of a lack of cleanliness of body, home and environment. This involved, for example, distributing accessible brochures about hygiene topics in the local languages. He also had to advise about the cleanliness of the market, shops, prisons and village schools. ${ }^{6}$

Rekest Bond van Geneesheeren 1906:14-7.

GB 3-12-1906 no. 15, Protest reorganisatiecommissie 1909:684.

According to Kohlbrugge (1909:395-6) there were only current and former health officers in it.

Bijker et al. 1908; Ind. Stb. 1910 no. 648, 649, 650; KV 1911:147.

These tasks were specified in the circular 1-6-1911 from the Civil Medical Service in Central Java (Van Haeften and Van Heel 1911:10-6). I assume that the situation in West and East Java did not differ much given the CMS's priority. 


\section{ETHICAL POLICY}

The names P. Brooshooft and C.Th. van Deventer are inextricably bound up with the ethical policy. ${ }^{7}$ The former was the chief editor of the widely read Semarang newspaper De Locomotief. Brooshooft, who was deeply impressed by the deplorable situation of the population during a trip around Java, petitioned twelve prominent Dutch people in 1888 to learn about the 'disastrous consequences' of the Dutch colonial rule. Upon his return to the Netherlands, Van Deventer, a long-time lawyer in Semarang, wrote an article in De Gids in 1899, entitled 'Een eereschuld' (A debt of honour), in which he argued for allowing some of the millions of guilders the mother country had extracted from the colony, the Batig Slot, to be used to help the native population: 'The restitution of the Indies millions, that is the debt of honour the Netherlands owes to the Indies, debt of honour because its discharge is required not by written legal grounds but by the higher law, which is called the law of honour and fairness' (Joop de Jong 2000:357).

The new ethical policy was officially announced by Queen Wilhelmina in the annual Royal Oration of 1901. The Netherlands 'as a Christian power' was obliged 'to imbue government policy with the understanding that the Netherlands has to fulfil a moral mission towards the population of these territories' (Van den Doel 1996:157). Therefore, politics should raise the population mentally and materially to a higher level of development, based on the Western model. The points of focus of the ethical policy were irrigation, transmigration and education. From irrigation and the construction of major hydraulic engineering projects, improved food production could be expected. From transmigration away from densely populated Java, a reduction in the population pressure and better means of subsistence for the migrants were predicted. Education was expected to produce the best welfare.

Ethical policy may have then become the official policy, but it did not mean that now all civil servants would act ethically. The department in The Hague issued a scathing official reaction to proposals from the director of Education, Religion and Industry, J.H. Abendanon, to improve the education available for natives. Abendanon was called by the department the 'director-utopist' and his proposals 'foolish' and 'too silly to pay much

$7 \quad$ This policy is comparable to the mission civilisatrice in France and the white man's burden in the UK. 
attention to them' (Van Miert 1991:58). In the Indies as well, only a small proportion shared the ethical philosophy, primarily civil servants. It was not in keeping with the planters' entrepreneurial interests, which were primarily served by low wages. The fact that Governor-General A.W.F. Idenburg gave the native personnel in the palace an afternoon off each week was considered too soft by the (Indo-)Europeans (Breton de Nijs 1960:121). Over time, 'ethical' became a term of abuse, a synonym for weakness (Van Doorn 1994:74-5). After 1920 the word 'ethical' was fully discredited and its use avoided (Van Doorn 1994:219).

Despite ethical policy, Table 8.1 shows that the expenses for education and the Civil Medical Service contrasted harshly with that of other sectors.

\begin{tabular}{|l|c|c|c|c|}
\cline { 2 - 5 } \multicolumn{1}{c|}{} & $\mathbf{1 9 0 4}$ & $\mathbf{1 9 0 9}$ & $\mathbf{1 9 1 4}$ & Total \\
\hline Civil Service & 11,907 & 12,336 & 12,634 & 129,887 \\
\hline $\begin{array}{l}\text { Construction projects } \\
\text { excl harbour projects }\end{array}$ & 11,537 & 13,778 & 26,026 & 171,582 \\
\hline $\begin{array}{l}\text { Agricultural, animal } \\
\text { husbandry, fishery }\end{array}$ & 807 & 1,208 & 2,138 & 13,540 \\
\hline Education & 4,906 & 8,306 & 13,116 & 90,301 \\
\hline Civil Medical Service & 3,145 & 3,502 & 7,544 & 50,864 \\
\hline
\end{tabular}

Table 8.1 Expenses for several departments in the colony (x $f 1,000)$ (Van Doorn 1994:147)

THE MEDICAL MARKET

Compared with 1850 the medical market situation in 1915 had changed in a number of ways.

\section{THE CONSUMERS}

The population on Java and thus the number of potential consumers of 'products and services' from the medical market increased greatly in this period. 


\begin{tabular}{|c|c|c|c|c|}
\cline { 2 - 5 } \multicolumn{1}{c|}{} & Natives & $\begin{array}{c}\text { Foreign } \\
\text { Orientals }\end{array}$ & Europeans & Total \\
\hline 1850 & $9,420,553$ & 147,168 & 16,409 & $9,584,130$ \\
\hline 1905 & $29,715,908$ & 317,183 & 64,917 & $30,098,008$ \\
\hline
\end{tabular}

Table 8.2 Population of Java and Madura in 1850 and $1905^{8}$

Taking care of oneself when ill was still common, also among Europeans. J.H.F. Kohlbrugge (1917:12), a physician with extensive Indies experience, warned Dutch doctors before they set off for the Indies, 'The physician who has just arrived from Europe is struck by the fact that almost everyone has some medical expertise. Many have lived for years in settlements without a physician and have had to treat themselves, their family and personnel, so many have only a paper doctor [handbook].'

\section{THE SUPPLIERS}

In comparison with 1850, there were new suppliers of products and services on the medical market in 1915. The number of private companies had increased, and they needed medical care for their personnel. The missionaries who founded their own medical facilities at the end of the nineteenth century formed a new party on the market. Also new were the dokter djawa and the native midwives. Of the 'old' suppliers the dukun still formed the largest group.

\section{DUKUN}

The strong position of the dukun on the medical market left the other suppliers with a decision to make. They could ignore that strong position, they could attack it by discrediting the dukun, or they could accept the dukun. Most Europeans probably chose the first option, which is why the European sources mention the dukun so rarely. But there were also European physicians who considered them a serious threat to Western medicine and its practitioners. In the preceding chapter enough has been said about Van Buuren and his crusade against the dukun bayi. J. Kwast,

\footnotetext{
$8 \quad K V$ 1849:4-7; KV 1907:appendix A. The composition of the population in 1915 was not recorded in either $K V 1916$ or $K V 1917$.
} 
a civil physician in Krawang around 1900, felt that dukun took advantage of every failed intervention of a Western-trained physician in order to produce negative publicity.

If we really want to seriously establish European therapy, failure will have to be avoided as far as possible. Every patient who is not cured offers ten times as much evidence as a cured patient among the conservative, difficult to convince village inhabitants. Each case like that is naturally used as negative publicity by dukun, etc. (Onderzoek mindere welvaart 1911:89)

From a well-educated native head Kwast had heard that dukun were spreading a rumour that the terminally ill were being poisoned in hospitals to finish them off quickly. It was also whispered that European surgeons just started cutting away, without asking the patients' permission (Onderzoek mindere welvaart 1911:91). In the novel entitled Doekoen by Madelon Székely-Lulofs, an idealistic Dutch surgeon in the coolie hospital of a company is in conflict with a female dukun who turns the natives against him. The novels by Székely-Lulofs, who lived in Deli for many years, are known for their authenticity.

Some accepted the strong position of the dukun. The previously mentioned physician Kohlbrugge (1917:12) advised doctors who wanted to go to the Indies not to oppose the dukun but to study the indigenous remedies and apply them because many of them were useful. A certain recognition of their position is also evident among those who wanted to train the dukun bayi according to Western insights. In the view of J. Schülein, civil physician in Tosari (Pasuruan) and board member of the Bond van Geneesheeren in Nederlandsch-Indië, each hospital should employ at least one qualified dukun, who could apply Javanese treatment methods. They would have to be supervised by a European doctor, 'who would correct their mistakes - but could also learn from them' (Schülein 1903:7). This reciprocity is practically unique. In his blueprint for an independent Civil Medical Service, W.Th. de Vogel (1906:39) envisaged training the dukun, because the population would not make use of Western physicians.

The general contempt of Europeans towards the dukun did not apply to the ethnographers G.A. Wilken, J.P. Kleiweg de Zwaan and L.Th. Mayer. ${ }^{9}$ Mayer considered it normal that the dukun had little knowledge 
about the human body because surgery was forbidden, but he was surprised to note how much knowledge a dukun did have and thought it unfair that they were always classed with the uneducated charlatans. He was not a doctor himself, but referred to experts such as C.L. van der Burg and C.H. Stratz, two famous medical specialists in the Indies, who had expressed their approval of the dukun (Mayer 1918:5-6).

Estimates of the number of dukun and dukun bayi around 1900 vary. The Colonial Report for 1894 stated that there were 17,639 dukun in Java and Madura ( $K V$ 1894:appendix A.IV); in later years no figures are given. That is considerably fewer than the 33,000 estimated by the regional administrators in a survey in 1902 that assumed one dukun per village (Bijker et al. 1908:265). The total population was about 28.3 million, which averaged one dukun for every 850 people. These figures are low in comparison with the ones from the study conducted at the beginning of the 1970s in Serpong, a district in West Java. At that time, the district had about 55,500 inhabitants spread over 15 villages. Almost all deliveries, 96\%, were assisted by the 77 dukun bayi (Lubis, Borkent-Niehof and Pudji Astuti 1973). That would mean five dukun bayi per village and an average of one dukun bayi for 720 people, in addition to the 'ordinary' dukun.

\section{CHINESE HEALERS}

In 1913 Boorsma was struck by the large number of apothecaries in a Chinese neighbourhood. He discovered that their knowledge was greater and their range of products wider than those of their native colleagues. Although the government did not exercise any control over them, they took their profession seriously. When preparing prescriptions, the apothecaries mostly applied the doctrine of signatures. Many also treated patients and were even called doctor (sinse). ${ }^{10}$

The Chinese medicines were well-known far and wide: in April 1903 the population urged the resident of Jakarta to employ a sinse as the resident of Surabaya had done to combat malaria, cholera, and especially the leprosy epidemic, and they could recommend a certain sinse. ${ }^{11}$ Some sinse had special medicines with which they successfully treated sick patients who could not be cured by European physicians. Sometimes they

\footnotetext{
1o Boorsma 1913:45-50; from 1 January 1905 he was head of the pharmacological laboratory, part of the Botanical Garden in Bogor.

${ }_{11}$ Report in the newspaper Pemberita Betawi, Rizal 2004:27.
} 
would sell their prescriptions, but not that often. After years of research A.G. Vorderman (1890:9) discovered some formulas, which he published. In another instance the governor-general asked the Vereeniging tot Bevordering der Geneeskunde for advice about whether it was desirable to start negotiations with the Chinese healer Tjo Kim Bin in Surabaya about buying his treatment method for leprosy. The general conclusion of their recommendation was that his method would have to be considered 'innocent (?) quackery'. Therefore, the governor-general decided not to pursue that course. ${ }^{12}$ Other doctors, in the Netherlands as well, were scientifically interested in Chinese preparations. ${ }^{13}$

The competition continued to increase, and sometimes it was unfair, as the government persisted in regulating only Western medicine and its practitioners. The civil physician in Kediri, Van Buuren, reported competition from Chinese dentists. After a Chinese man had trained with a European dentist, he established a private practice and charged lower fees than the European dentist. The Civil Medical Service inspector Vorderman accused a Chinese man with setting up an unauthorized dental practice in Jakarta. In both cases the government did not take any steps (Van Buuren 1898b:18, 20).

The Colonial Report for 1894 mentioned 241 sinse on Java and Madura and 198 in the Outer Islands. On Java almost half of them were established in Jakarta (84) and Surabaya (29); in the Outer Islands there was a high concentration in the residencies of Sumatra's East Coast (67), Western Kalimantan (41) and Riouw (26) ( $K V$ 1894:appendix A.IV).

\section{EUROPEAN DOCTORS AND MIDWIVES}

Around 1900 there was a shortage of European doctors, given the increased number of Europeans in the colony and the ethical policy that introduced new tasks. In 1902 the need had grown so great that the army administration issued a circular cancelling all leave in Europe. ${ }^{14}$ The

\footnotetext{
12 Faarverslag over 1903 1904:XVI; in the same report: LXXII F.S.W. van Hasselt discussed the leprosy treatment of Tio Kim Bing.

13 Vorderman (1890:11-4) named: J. van der Wiel, apothecary in Batavia, 'Chineesch geneesmiddel tegen diphteritis', GTNI 1881:303-6; H. Wefers Bettink, 'Obat orang sakit lehen [leher]', Nieuw Tijdschrift voor de Pharmacie in Nederland 1887:171- 6, 'Chineesch middel tegen diphteritis', Nieuw Tijdschrift voor de Pharmacie in Nederland 1888:20-3; J. Douwes, military apothecary, 'Het onderzoek van de 4 poeders van de Chinees Si Mah In te Batavia', GTNI 1887:232-44.

14 D.A. Boon, 'Boek der herinneringen', manuscript KITLV, 1934 edition, 104.
} 
shortage of healers produced tension between European physicians and the colonial government. In particular, Director of Education, Religion and Industry Abendanon received much blame. Often European physicians charged with the Civil Medical Service covered more than one district without receiving a higher allowance. In 1902 the board of the Bond van Geneesheeren in Nederlandsch-Indië asked the governorgeneral whether this was official policy and considered fair. This step was brought about by the situation in Pekalongan, where due to transfer of the dokter djawa, the civil physician $\mathrm{H}$. Koppeschaar was not only in charge of the Civil Medical Service in the main town of Pekalongan but also responsible for the district of Batang. It was impossible to carry out his tasks properly in both districts, so he had to abandon his private practice. ${ }^{15}$ This was clearly an excessive burden, but the chair of the same Bond van Geneesheeren, W.J. van Gorkum (1904:11), also complained about competition: 'Let us not forget that on Java the competition among the doctors increases day by day'.

According to the head of the Medical Service, M.Th. Reiche, the interest among European midwives to work in the Indies increased greatly around 1875; 'the profitability of the position' would explain this. ${ }^{16}$ We noted before that European midwives in the Indies earned as much in a month as their colleagues in the Netherlands did in a year. The board of the Bond van Geneesheeren recorded an excess of European midwives, who competed fiercely. It is alleged that they carried out forceps deliveries unnecessarily to promote their expertise. When they were reminded of their obligation to summon a physician for complications, they said that 'nothing like that had ever happened', but the following year there were suddenly no complicated deliveries (Bond van Geneesheeren 1910:92-3). The competition apparently existed not only between midwives but also between midwives and physicians. Just like in the Netherlands the rivalry focussed on the use of obstetric instruments. The figures do indeed reveal an increase in the number of private midwives: from 11 to 14 between 1876 and 1879 (KV 1876:122; KV 1879:121). This was probably due to the larger number of European women in the colony. The midwives were mostly located in the larger towns on Java (eight in Jakarta, two in Surabaya and one each in Bogor,

\footnotetext{
$15 \quad$ Rekest Bond van Geneesheeren 1903:23-7.

16 His recommendation to the director of Education, Religion and Industry 28-6-1873 no. 994, Historisch overzicht 1898:34.
} 
Semarang, Yogyakarta); the only smaller place with a private midwife was Bondowoso (Besuki) (KV 1880:103).

\section{EUROPEAN LAYPEOPLE}

Kohlbrugge (1917:12) had already pointed out that many people in the Indies treated themselves using a paper doctor. He was referring to the recipe books published by Indo-European ladies at the end of the nineteenth century. Boekoe obat voor [sic] orang yang toewa dan anak-anak (Book with medicines for young and old) by nonja van Gent-Detelle appeared in 1875 and was already in its fifth edition by 1883. Doekoen djawa oetawa kitab dari roepa-roepa obat njang terpake di tanah Djawa (Javanese dukun or book about all sorts of medicines used in Java), written by nonja van Blokland, appeared in 1885 and had a third edition in 1899. It is surprising that both books enjoyed a certain popularity, as testified by the reprints, because the first contains around 500 prescriptions and the second 1800, one after another without any arrangement. Not all ladies wrote; some only had practices such as 'mother Abbink' in Surabaya and Mrs. Stoll in Semarang (Kohlbrugge 1910:81). A physician anonymously published the diet for gastrointestinal diseases from the latter. ${ }^{17}$ The best known author was J. Kloppenburg-Versteegh. In contrast to the other two, she did not use the Indies title nonja, which is how married European women were addressed, and she did not publish in Malay. Clearly, the European population group was growing so much that the number of Europeans who did not know Malay had also increased. Various reprints were made of her book Indische planten en haar geneeskracht (Indies plants and their healing properties), published in $1907,{ }^{18}$ including an edition in Malay in 1928. Rob Nieuwenhuys described its importance for planters in the interior where there was, 'No doctor, just a dukun or the advice of old Indies or Indonesian women or the herbals of Mrs. Kloppenburg-Versteegh' (Nieuwenhuys 1972:342). Her books were consulted frequently and even revered (Nieuwenhuys 1972:602). They are a miracle of order in comparison with the books of her predecessors.

Most European physicians wanted nothing to do with these ladies.

$17 \quad$ Indisch dieet 1895.

18 In 1907 two editions appeared that differed more from each other than the reprint in 1911. The latter was given another title, Wenken en raadgevingen betreffende het gebruik van Indische planten, vruchten enz [Tips and advice regarding the use of indigenous plants, fruits, etc.]. 


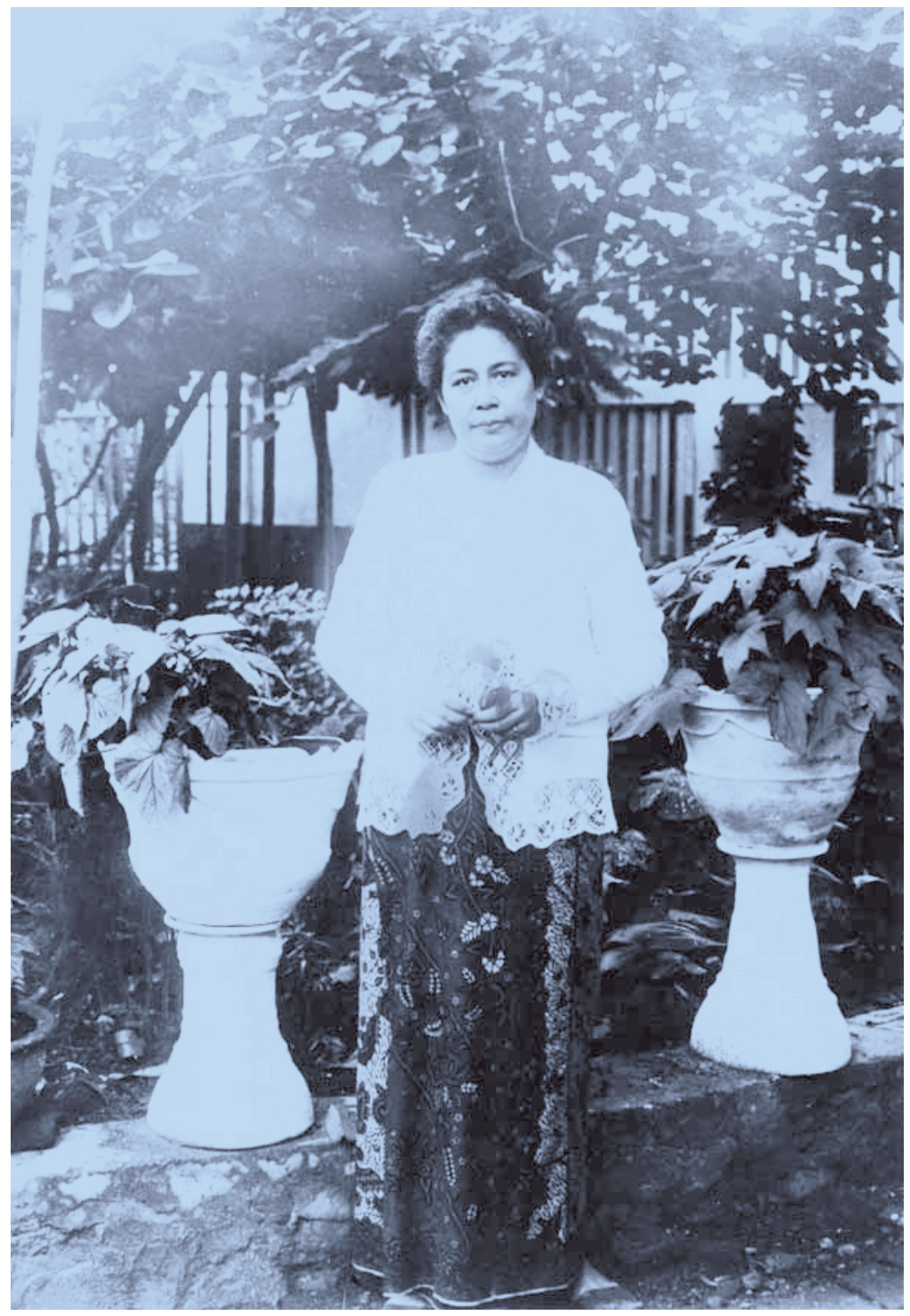

Mrs. Kloppenburg-Versteegh (photo collection KITLV 15369) 
Health officer J.G.X. Broekmeyer (1856:39) wrote as early as 1856, 'The many native nonja, who administer medicines now and then, and some of whom have a certain reputation, have if it's possible even less knowledge about matters than the dukun'. The physician C.L. van der Burg, also anything but positive, devoted four pages in his standard work, De geneesheer in Nederlandsch-Indie to lambasting the evil that these ladies wrought. $\mathrm{He}$ hoped to warn the European physicians newly arrived in the Indies, but he did not have any illusions that his writing would have any effect, conceding that this 'large group of amateurs in medicine' was held in high esteem by all the Europeans. The head of the Medical Service, G. Wassink, called some of these ladies 'shorthand prescription books in parchment covers'. ${ }^{19}$ In his official speech at the 25-year anniversary of the Vereeniging tot Bevordering der Geneeskundige Wetenschappen in Nederlandsch-Indië in 1877, Van der Burg (1877:20) repeated these 'bon mots'. The Bond van Geneesheeren even considered establishing a society against quackery in response to Kloppenburg's book, but decided against it when it noted the lack of legislation in this field. Instead, it reviewed the book and denigrated it as 'a worthless pamphlet' (Benjamins and Damsté 1907:15-25).

There were also European physicians who appreciated these ladies, such as Vorderman, at that time the third municipal physician in Jakarta. He strongly criticized the standard work of Van der Burg: 'Dr. Van der Burg repeatedly scoffed at Mrs. van Gent's booklet, but he could have learned a lot from it, at very least the names of indigenous medicines' (Vorderman 1886:18). Vorderman (1886:23) considered nonja Van Blokland's booklet invaluable for anyone interested in the study of native therapy or pharmacology. Kohlbrugge (1910:81) described how the head of the Medical Service, 'active at the time of my arrival in the Indies, told me that he had more faith in nonja X than in his colleagues'. He himself considered 'the use of indigenous medicines by wise European ladies' as competition, but he felt it was unfair to oppose it. It made more sense to gain knowledge about their remedies and apply them because many were useful (Kohlbrugge 1917:12).

The popularity of the books written by these ladies made some European doctors overly critical. Probably they were afraid of the competition: after all, the books could only be used by people who could 
read, primarily Europeans, who were their potential patients. Their commentary also evidenced a touch of racism and sexism: the ladies were Indo-European. They were strangely silent about other lay doctors such as the male European controleurs.

At locations where there was no medical assistance, medicines had always been provided to the controleurs with a 'paper doctor' serving as their guide, a thin booklet with instructions for the most commonly occurring diseases and the most widely requested medicines, a situation that continued until the Second World War. ${ }^{20}$ H. Doeff (1896:106) described that when on an inspection tour; he first presided over a court and then dealt with the sick.

Carbolic soap, iodoform, plasters and cotton wool were produced, and the controleur is promoted to doctor. - One person needs bandaging, - another asks for a remedy against stomach-ache or worms. The office is transformed into an apothecary, bottles of castor oil with laudanum solution are given out; large groups of elderly gentlemen desire a remedy for rheumatism. A strong smell of medicine fills the air.

Often the controleur's wife carried out this role, such as Saar Lulofs, the mother of the writer Madelon Székely-Lulofs, who had been trained as a nurse before departing for the Indies around 1900. When her husband was appointed controleur at Lake Maninjau (Sumatra's West Coast), she held an outpatient clinic twice a week. In the beginning she did not have any patients because they all went to the dukun. Finally, a seriously injured woman turned to Saar Lulofs as a last resort; the woman had spilled a can of boiling sugar syrup over her leg and the wound had begun to fester after the dukun covered it with clay and banana leaves. Saar Lulofs agreed to treat her only if she moved into one of the servant's quarters temporarily. After a family consultation, she was given permission to do so. Three months later she returned healthy and well to her village. From then on, the sick and wounded flocked to Saar's improvised clinic. When she did not know what to do for a particular disorder, she would contact the health officer in Bukittinggi through the primitive telephone connec-

2o Jongejans-van Ophuijsen 1936:47. From 1890 students training to be civil servants in Delft - who were aiming at the potentially isolated posts - took a course in bandaging and elementary surgery, Brinkgreve 2009:51. 
tion, who would mostly prescribe quinine pills, castor oil or balsam of Peru (Okker 2008:28).

\begin{tabular}{|l|c|c|}
\hline Garegiver & $\begin{array}{c}\text { Number in } \\
\mathbf{1 9 0 0}\end{array}$ & $\begin{array}{c}\text { Number in } \\
\mathbf{1 8 5 0}\end{array}$ \\
\hline Dukun, incl dukun bayi & $33,000(?)$ & $11,421(1884)$ \\
\hline Chinese doctor, sinse & $241(1894)$ & $268(1884)$ \\
\hline European health officer charged with CMS & 15 & 19 \\
\hline $\begin{array}{l}\text { European physician } \\
\text { (municipal, private, civil) }\end{array}$ & $8+38+42$ & $5+15+9$ \\
\hline $\begin{array}{l}\text { European physician + health officer in } \\
\text { special functions }\end{array}$ & Ca 20 & 3 \\
\hline European apothecary (municipal, private) & $2+41$ & $3+9$ \\
\hline European dentist & 8 & 0 \\
\hline European midwife (municipal, private) & $4+30$ & $4+?$ \\
\hline $\begin{array}{l}\text { Native midwives (with/without allowance; } \\
\text { throughout the Indies) }\end{array}$ & $36+6$ & 0 \\
\hline Dokter djawa in government service & 90 & 0 \\
\hline Dokter djawa in private service & 4 & 0 \\
\hline
\end{tabular}

Table 8.3. Number of medical caregivers for the CMS on Java around $1900^{21}$ and 1850

Comparison with the table from 1850 shows three new groups of suppliers on the medical market: European dentists, native midwives and dokter djawa. The figures are not necessarily accurate, but there are a few evident developments. The number of private European physicians, midwives and apothecaries had increased. This was associated with the increase in the number of European consumers. The number of natives and Chinese also rose in this period; probably this also led to an increase in the number of their healers, but relevant data are lacking.

${ }_{21}$ KV 1901:appendix T; Almanak Nederlandsch-Indië 1900. Numbers for 1850 are given in table 2.1. According to Pols (2009:178) there were slightly fewer than 300 European-trained physicians in the Dutch East Indies in the 1880s; by 1900, this number had risen to almost 400 . It may be presumed that in his numbers Pols includes the military physicians. 
Along with the caregivers there were other suppliers of products and services on the medical market, and different types of hospitals and clinics supplied health care.

\section{MISSIONS}

In the beginning of the nineteenth century, the government continued the non-intervention policy of the VOC in Islamic areas. According to the Government Regulations from 1854 (article 123), a missionary could work in the archipelago only after obtaining permission from the governor-general. At the end of the century, the policy changed. Missionary work and missions had been found to be beneficial for promoting health care and education. The ethical policy favoured the missions, certainly with a Christian politician like A.W.F. Idenburg as minister of Colonies and as governor-general; he played an important role in the colonial politics for an almost unbroken stretch between 1901 and 1919. Being a good Protestant and endorsing the ethical policy, he envisaged a role for the missions in the fields of education and medical care (Houben 1996:73-4). His firm support of the missions aroused irritation because it was feared he wanted to convert the Indies to Christianity by force. Part of the press and some politicians labelled Idenburg 'the fanatic on the throne' (Schouten 1980:14).

In the second half of the nineteenth century, the missions started work on Java. Every missionary society had its own territory in the Indies where missions were run, funded by subsidies from a religious community in the Netherlands. In the beginning the missionaries were generalists: preacher-teacher-doctor. Before a missionary was sent out, he followed an elementary medical training (Wijkhuis 2006:45). Medical care was found to be an effective and easier manner of gaining contact with the population and winning souls. When the missionary S. Coolsma arrived on Java in 1865, he was assigned to Cianjur (Preanger) just before a cholera epidemic broke out. As there were no other medical facilities, the population turned to Coolsma, who had a well-stocked medicine chest and a few simple instruments. Over time visiting the sick became an important part of his work; he had 50 patients per day (Coolsma 1924:55-6). Only in 1893 did the missions send out the first physician, J.G. Scheurer. 
Mojowarno and Yogyakarta were two showpieces of the medical missions. Both lay in the Principalities, which had been closed to the missions the longest by their rulers. The sultan of Yogyakarta didn't give up resisting until 1890, and then only if it would not lead to commotion or disturbance of the peace (Margadant 1897:390).

\section{MOJOWARNO}

In 1894 H. Bervoets and his wife, L.L. Bervoets-van Ewijck, were sent to the small missionary hospital in Mojowarno (Surabaya), which had a thriving Christian community. The couple were very active in training nurses and midwives. Along with subsidies from their religious community in the Netherlands, they received financial support from the nearby sugar factories, but the drop in sugar prices on the world market reduced or stopped this contribution (Bervoets-van Ewijck 1897:178). The hospital also received contributions from local regents: along with Mojokerto and Jombang, four others each donated five to six guilders per month (faarverslag Modjowarno 1898:108-11).

In the Indies each missionary, just like the controleurs in the interior, was given a box of medicines from the government. ${ }^{22}$ Initially, Bervoets fell under the same regulation as a controleur and received only small quantities of the 'simplest medicines'. ${ }^{23}$ At his request he was given the quantities of medicines he specified in 1895, at first incidentally but then consistently after $1896 .{ }^{24}$ Bervoets and his wife could not cope with the flood of patients; at their request, a Christian dokter djawa, Ismael, was seconded to the hospital in 1898, and his salary was paid by the government. ${ }^{25}$ The hospital in Mojowarno continued to overflow, necessitating expansion of the building and the staff. A second missionary physician arrived. The government subsidy was doubled from $f 3000$ in 1899 to f6000 in 1901 (KV 1901:83). From 1906 government subsidies for private hospitals were permanently incorporated in the budget, and thus the missionary hospitals were also covered (Ind. Stb. 1906 no. 276). A description of the hospital from 1896 clearly shows its popularity: it was modern

22 GB 13-7-1894 no. 12, Bïblad 4992; two missionaries in Jepara had a case of medicines on hand from 1872, Archief Schoute Japara, 1872.

$23 \quad$ Regeering en Modjowarno 1898:12.

${ }_{24} \quad$ Regeering en Modjowarno 1898:12-4; KV 1898:86.

$25 \quad$ Nogmaals Modjowarno 1898:87-8; KV 1898:86. 
and fully equipped according to scientific criteria, with instruments that could not be found in the government hospitals (Offerhaus 1896:357-60).

\section{PETRONELLA HOSPITAL}

The first missionary physician on Java, Scheurer, ended up in Yogyakarta after some wandering about, where he founded the Petronella Hospital in 1897. The mission's focus on the population is illustrated in an advertisement placed by Scheurer:

The undersigned feels compelled to inform the European public that his duties as a missionary doctor do not permit him to run a civil practice, either inside or outside the clinic. He can only be consulted after discussion with and approval from the treating physician. (Wijkhuis 2006:35.)

Among the population Scheurer was known as doctor toeloeng, the doctor who helps (Van Kol 1903:783). In contrast to health officers who were frequently transferred, the missionary doctors remained working in one location for a long time and devoted themselves entirely to treating the natives, establishing a good connection with the population, which was an important precondition for building up trust among future patients.

His successor, H.S. Pruijs, invented the Petronella or Yogya system, which would later be a model for all missionary hospitals and for many hospitals outside the missions (Verdoorn 1941:148). It consisted of a centrally positioned hospital with clinics in the smaller towns or larger villages arranged in a circle around it, run by certified native personnel under the supervision of a physician from the central hospital. In a broad circle around the subsidiary hospitals, outpatient clinics were regularly held in the villages (Peverelli 1947:90). Part of this system involved training the personnel to be mantri-nurses and midwife-nurses. This was one of the most important tasks of the Dutch nurses in the hospital, and around 1900 one was Jo Kuyper, the prime minister's daughter (Van der Woerdt 2004:39-40). Because there was no missionary school in Yogyakarta, orderlies and other unskilled workers were trained there as hospital attendants (Sciortino 1996:31). They were primarily men who could be more easily employed in the outpatient clinics than women who were tied more to their homes. The mantri-nurses were also called assistant doctors or village doctors (Sciortino 1996:35-6). 


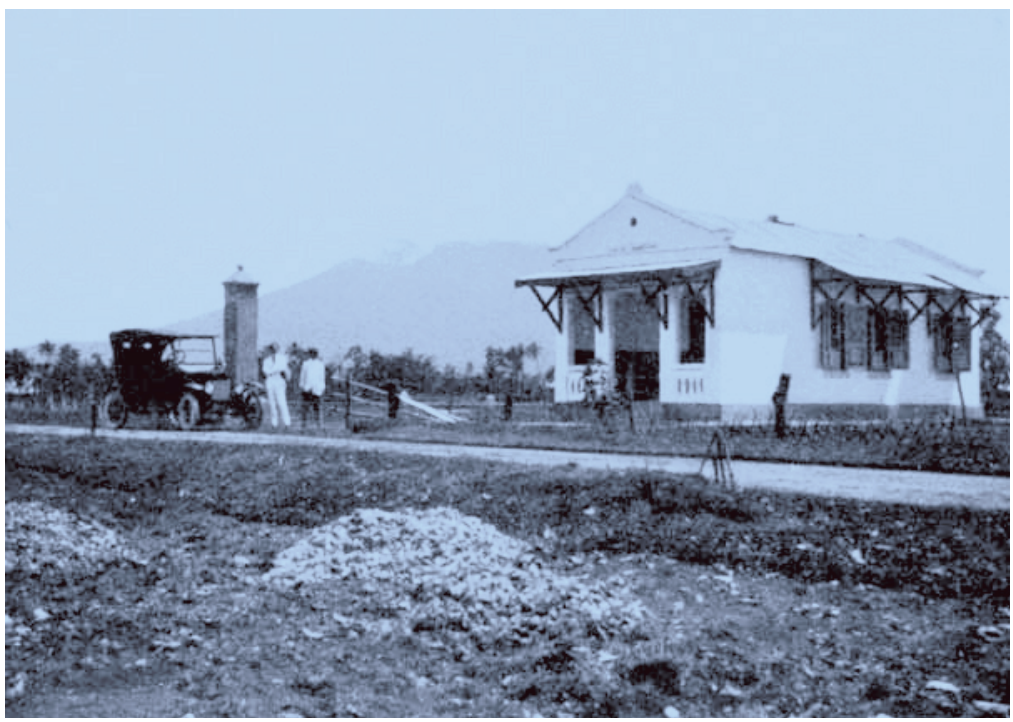

Indische arts Zainal in front of an outpatient clinic (Zainal 1926:320)

\section{COMPANIES}

The Agrarian Law of 1870 led to an influx of private companies whose business interests required the provision of medical care for their engineers and workers. Despite offering a good salary, it was difficult to attract engineers from the Netherlands because of the unhealthy climate and the minimal medical facilities. In addition, there was enough work in the Netherlands (Ravesteijn and Ten Horn-van Nispen 2007:280). Good medical care for the engineers and their families was thus essential. The companies usually concluded a contract with a doctor who in return for 75 to 100 guilders per month was obliged to treat ten to fifteen families, mostly of the European personnel; the doctor generally only saw the native personnel when there had been accidents (Kohlbrugge 1917:7). The relationship between the company and the European physician could become tense, especially because for many European doctors the contract with the companies provided their main income. For example, in 1901 ten sugar factories in Jombang (Surabaya) had an arrangement with the local civil physician, J. Coronel. This lasted until the end of 1904, when a conflict with the president of the group of sugar manufacturers brought 


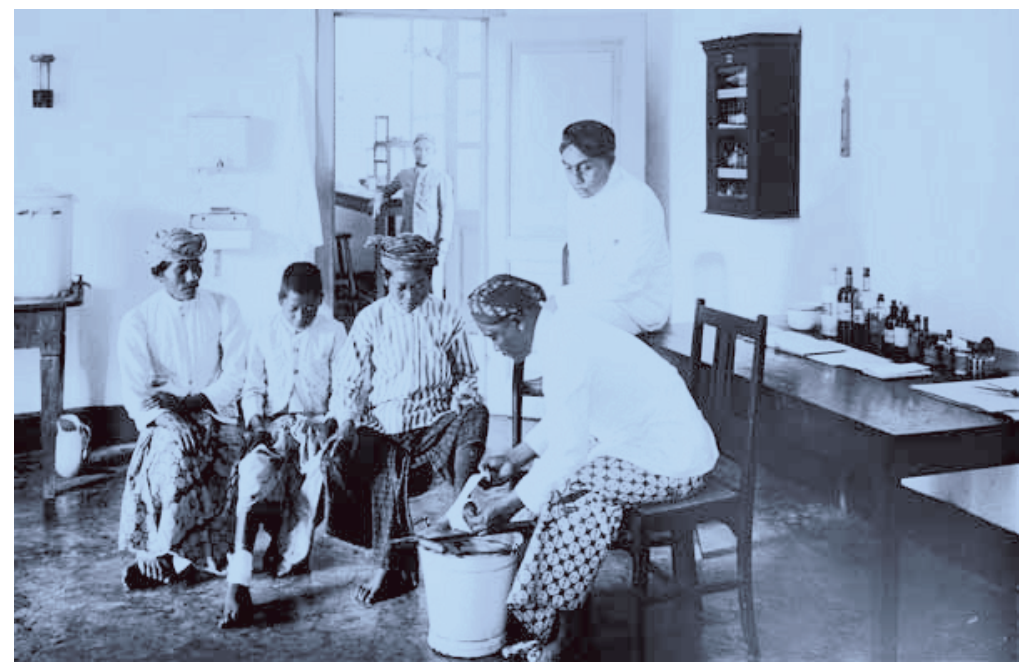

A dokter djawa in the outpatient clinic of a kapok company in Central Java in 1927. From the clothing the dokter djawa is probably the one who is watching. (photo collection KIT)

it to an end (Schülein 1905a:23; 1905b:47-80). In another instance, the company was in charge of the hospital and decided who would be employed as a nurse and who could be a patient. The European physician felt excluded. Although he considered resigning, he did not sign the submitted letter. ${ }^{26}$ This does not allow us to determine how the situation ended.

A 1890 circular from the director of Education, Religion and Industry to the regional administrators stated it was forbidden to admit employees of private companies to the native hospitals outside the three main towns. ${ }^{27}$ As companies were established outside the towns, they had to arrange medical care for their employees themselves. Some used the missionary hospitals, and a few even built their own hospitals; in 1900 there were three company hospitals on Java (KV 1902:appendix R). From 1900, sick natives from private companies were admitted to the native hospitals if there was space and the relevant company paid the nursing

${ }_{26} \mathrm{X}$, 'Over de verhouding van geneesheer tot ziekeninrichting', Bulletin van den Bond van Geneesheren in Ned.-Indië. 1911:3-8.

${ }^{27} \quad$ Circular 6-10-1890, KV 1891:134. 
fees (65 cent per day) and any funeral costs. ${ }^{28}$ The last remark did not bode well. However, this was an improvement, but it did not solve the problem for the companies. The Solosche Landhuurders Vereeniging (Solo Tenants Association) submitted a request to the government in 1902 asking for more dokter djawa and offering to help pay for new hospitals for natives (Kohlbrugge 1904:11-2, 17). The sugar manufacturers in Tegal and the surrounding region set up a society in 1911 with the aim of providing nursing care for the sick of all population groups working for the companies (Vereenigingen 1921:541). Some sugar companies happily employed personnel trained by the missions in their own hospitals. For example, a Javanese couple who had been trained as nurses in the Petronella Hospital worked around 1910 in a clinic of a sugar factory nearby (Van der Woerdt 2004:154). Years later the sugar syndicate rather bluntly expressed that medical care was one of the indirect means to promote profit (Stokvis-Cohen Stuart 1931b:486). Women and children were not included for a long period until an epidemic killed off many coolies (Stokvis-Gohen Stuart 1931b:483).

DELI

Employees from China, Malaya and Java were recruited for the plantations and mines on Sumatra; forced labourers were also employed. The working conditions were so bad that many coolies ran away. The entrepreneurs on Sumatra's East Coast asked the government to again make premature termination of an employment contract by the employee punishable. The government agreed and issued the Coolie Decree in 1880: an employer could punish a coolie for laziness or for running away. In the Decree the employers' obligations were also specified, such as the provision of accommodations and medical care (Lucas 1986:801). The planters in Deli combined forces to improve the health of their personnel. Around 1900, along with a number of central hospitals, one shared pathology laboratory was established in Medan, which would become known through the work of two physicians from the Senembah Company, W.A.P. Schüffner and W.A. Kuenen. 'Coolie-diseases' such as dysentery and cholera were eradicated (Bossenbroek 1996:59). Peverelli (1947:93), who was head of health care in West Java just before World 
War II, said, 'One of the most splendid and classic examples of what rational care for the public health is capable of in the tropics was provided by Deli, especially the Senembah company'.

This praise contrasted strongly with the misery described by the lawyer J. van den Brand in his brochure De millioenen uit Deli (The millions from Deli, 1902). This booklet and the fuss it generated forced Minister of Colonies Idenburg to order an investigation of the working conditions in 1903, which was conducted by the public prosecutor J.L.T. Rhemrev. The Rhemrev report described a large number of disconcerting cruelties and was kept a secret until the 1980s. ${ }^{29}$ During the budget debates in the Lower Chamber in November 1904, the social-democrat H. van Kol quoted from Van den Brand's brochure:

[A]nd then the hospital of a coffee company where a pestilent stench issued from a lattice window and derived from two Javanese men, eight Javanese women, all fatally ill and a corpse that had been lying there for 24 hours, all crushed in a space of a few square meters, without water, without a toilet bucket, where they relieved themselves on the ground, mixed it with sand and then shoved it outside through a crack. (Idema 1924:180.)

In Deli, unlike in Java, some said midwifery assistance was provided for the employees: as many deliveries as possible were done in the central hospital under the supervision of a dukun bayi (Haneveld 1989:76). This does not match the description of the situation in Deli at the start of the twentieth century given by Madelon Székely-Lulofs in her novel Doekoen, which is assumed to be true to life.

\section{GOVERNMENT HOSPITALS}

Native hospitals established by the government were intended primarily for nursing the sick who had been in conflict with the police and the authorities or had displayed immoral behaviour, such as prostitutes, prisoners, mentally ill patients and forced labourers, along with seriously injured patients and those with contagious diseases (Kohlbrugge 1904:4). The hospital itself was not attractive: 'Gloomy walls of tarred bamboo,

$29 \quad$ Van Doorn 1994:33-4. In 1987 Jan Breman brought this into the open in his thesis: Koelies, planters en koloniale politiek. Dordrecht: Foris. 
here and there partly mouldy, ravaged by insects, without light, with hard wooden beds, on which lay grimy yellowish brown mats, hard leather rolls as pillows, dirt floors, here and there marked red from sirih spitting' (Degeller 1910a:1-7). The reports of the Civil Medical Service inspector form a series of wretched descriptions: 'The entire clinic is an old hovel'; 'The woodwork is mouldy in places, and [...] warnings ring out in the prostitutes' ward to bring a strut quickly to shore up the roof'; 'The stocks of drinking cups and tinned food are rusted through in places' ${ }^{30}$ The description of conditions in the municipal clinic in Semarang paints a similarly gruesome picture. The contagious diseases ward was the entrance hall to the mentally ill ward. The municipal physician W.Th. de Vogel, together with the dokter djawa on duty one night, gave a subcutaneous transfusion of saline solution to a newly arrived cholera patient who was fatally ill. The mentally ill patients were woken up by this and began to shout, scream and curse from the bars of their cells. The patient died during this infernal racket, 'and his last impression of life was this scene, resembling a description of Dante's hell'. ${ }^{31}$ It was thus not surprising that natives were not keen to be admitted. 'Decent kampong-women' would in any case not let their men go to a clinic where prostitutes were being treated (Degeller 1910a:3). L. Steiner, municipal physician in Surabaya, compared the government clinics and the one in Mojowarno:

I have been to Mojowarno. What a contrast with our municipal clinic! A friendly, open building, no neighbours nearby, no enclosing wall, no bolts or iron bars. The patients move about without restraint! The sick: all of them simple village inhabitants; no forced labourers, no prostitutes, not one orderly and especially: no restless mentally ill patients. Once you have seen Mojowarno, you are no longer surprised to hear that the natives, who abhor the municipal clinic, like to be admitted there. (Verdoorn 1941:124)

Under the influence of the ethical policy, the government felt increasingly responsible for the health of the inhabitants. In 1901 the native hospitals were opened to poor natives. However, almost all natives could

\footnotetext{
3o Report 8-11-1902 on Jombang; report 18 and 20-7-1903 on Bandung; report 5-9-1903 on Tasikmalaya, Bijker et al. 1908:199, 200, 202.

$3^{1} \quad$ Peverelli 1947:18; unfortunately, he does not give a source for this quotation.
} 
be labelled 'poor'. ${ }^{32}$ In the native hospitals status was not respected, as in Europe, with all associated consequences: a mandur would not lie next to a coolie, and a district head definitely would not (Degeller 1910a:3).

\section{NEW FACILITIES}

Around 1850 most native mentally ill patients were cared for at home. Only a small group could be accommodated in prisons or institutes in the three main towns: the Chinese hospitals in Jakarta and Semarang, the municipal clinic in Semarang, the municipal clinic and the Pegirian poorhouse in Surabaya (Bauer and Smit 1868:33-5, 38). The European mentally ill patients stayed in a ward of the military hospital in the three main towns: in Jakarta from 1836, in Semarang from 1849 and in Surabaya from 1863 (Den Hertog 1991:62). In 1865 it was decided to establish two mental health hospitals, one in West and one in East Java. ${ }^{33}$ Shortly thereafter, two European physicians were sent to the Indies to design the buildings and arrange for the mentally ill patients (Krankzinnigenverpleging 1918:446). They were allowed to take their time. First of all, they visited a number of insane asylums in Europe. In 1867 they arrived in the Indies, and a year later they issued their report (Bauer and Smit 1868). It was decided to establish an institute with 400 beds near Bogor, but construction only started in 1875 (Latumeten 1936:39). In 1882 some of the hospital was in use (Krankzinnigenverpleging 1918:446), with two European physicians and a part-time dokter djawa working there in the beginning. ${ }^{34}$ Nursing personnel were trained there ( $K V$ 1899:122; $K V$ 1901:83). The male patients worked in a sawmill, a bookbinder's or a smithy, and the non-European ones often worked the land. ${ }^{35}$ The women did sewing and household chores ( $K V$ 1897:151). With the opening of Bogor, it was decided to expand the mental health wards of the military hospitals in Semarang and Surabaya. Later, in 1901 and in 1906, these subsidiary clinics were abolished again ${ }^{36}$ because a second mental health institute was opened in Lawang (Pasuruan) in 1902. ${ }^{37}$ There was considerable criticism of the luxuriousness of this institute, especially as

$32 \quad$ GB 25-4-1901 and GB 6-6-1902, KV 1901:83.

33 KB 30-12-1865 no. 100, Krankzinnigenverpleging 1918:446; Latumeten 1936:39.

34 Besluit GG 9-3-1881 no. 34, Ind. Stb. 1881 no. 74; KV 1897:150.

35 In those days manual labour was considered typically native, Bosma 2010:108.

$3^{6} \quad$ Krankzinnigengesticht te Lawang 1907:1292.

37 GB 23-4-1902 no. 22, Ind. Stb. 1902 no. 180. 
there was an enormous shortage of normal hospitals for natives. ${ }^{38}$ The need for good care of mentally ill patients remained so pressing that the budget for 1912 included auxiliary clinics for calm native patients near Lawang. They were meant to be run by native doctors and regularly inspected by a European doctor from the main clinic. ${ }^{39}$

Spas remained popular with Europeans and natives. The small private institute at the hot mineral springs in Krakal (Bagelen) was occasionally subsidized by the government (KV 1890:125). In January 1897 the head of the Medical Service charged L.J. Eilerts de Haan, director of the Vaccine Institute and the Pasteur Institute, with preparing a proposal for an institute for massage and mechanotherapy, which would be affiliated to the military hospital. In March of that year the institute was opened, with Eilerts de Haan (1898:288-96) as its director; he had earlier expressed interest in massage. In Bogor in 1880 a hospital was opened for native sufferers of beriberi. In particular, soldiers from Aceh were brought here (KV 1880:104). Although the cause of beriberi had been discovered at the start of the twentieth century thanks to research conducted in the Indies by C. Eijkman, G.Grijns and A.G. Vorderman, the hospital would exist for a long time. ${ }^{40}$

\section{PRIVATE INITIATIVE}

There were other initiatives to set up or maintain hospitals alongside the private ones from the missions and the companies. Native health care facilities were supported by a native tax, the zakat, especially in the Priangan. Islam requires the population to pay zakat to the village clergy. In the Priangan the regents, who enjoyed a type of self-administration (the Priangan system), enforced payment of the zakat. ${ }^{41}$ If people from other districts were admitted to Bandung, Cianjur or Sumedang, the clergy from those districts paid the hospitals a fee of 15 cents per day from this zakat. ${ }^{42}$ When the Priangan system was abolished in 1871, the zakat gained a more voluntary status, as elsewhere. This endangered the

\footnotetext{
$3^{8} \quad$ Kohlbrugge 1904:17. The reorganization Commission spoke of 'too luxuriously outfitted', Bijker et al. 1908:120.

$39 \quad$ Extracten begrooting 1912 1911:7, 9-10.

$4^{\circ} \quad$ It was still being referred to in 1917, Geneeskundige Dienst 1917:764.

$4^{1} \quad$ The Priangan system dated from the VOC period; in it, the native population cultivated coffee under supervision of their own heads, Bosma 2010:274 n43.

$4^{2} \quad$ Archief Schoute Preanger, 1865.
} 
continued existence of the clinics, and the government took over their management. ${ }^{43}$

In several places the Chinese established hospitals, for example., in Tanjong Pinang (Riouw), Medan, Tanjong-Pura (Lower Langkat) and Binjei (Upper Langkat) (KV 1879:122; KV 1899:122). Various private sanatoria, including one in Gadok (later Sukabumi) and Sindanglaya (both in the Priangan) were subsidized by the government in exchange for admitting civil servants ( $K V 1879: 122 ; K V 1886: 104)$. In 1891 a health resort was opened in Tosari (Pasuruan) on a trial basis; treatment was in the hands of a health officer (such as Kohlbrugge and Schülein). ${ }^{44}$ In 1905 the government revoked the subsidies for Sukabumi, Sindanglaja and Tosari against the wishes of the reorganization Commission. ${ }^{45}$

From the end of the nineteenth century, different European committees were founded with the aim to set up hospitals. In Jakarta the Vereeniging voor Ziekenverpleging in Nederlandsch-Indië (Society for Caring for the Sick in the Netherlands Indies) was established in 1895. It rented a building in which a deaconesses' hospital - also known as the Cikini Hospital - was opened; in the course of 1897 it was transferred to a better location. It cared for the sick of all classes and denominations; treatment was free of charge for the poor. Surabaya and Semarang copied this initiative in 1897 and Deli in 1899. ${ }^{46}$ At the beginning of the twentieth century, a flood of such initiatives came into being. From 1906 the government structurally subsidized the private hospitals (Ind. Stb. 1906 no. 276). The new Civil Medical Service focussed more and more on prevention and hygiene; setting up and maintaining hospitals were no longer considered government tasks. The military hospital in Pelantungan (Semarang) in 1908 was turned into a leprosy clinic, and its management was transferred to the Salvation Army; the government continued to support it financially. ${ }^{47}$

There were also individual initiatives. The civil physician Kohlbrugge set up a native hospital during his posting at Sidoarjo (Surabaya), which was financed by Europeans. This seemed to him a good way of bringing Europeans and natives together after a riot in which many Javanese

\footnotetext{
43 Resolution 26-5-1871 no. 28, KV 1871:110; Schoute 1936:302-3.

$44 \quad$ GB 5-8-1891 no. 1, KV 1891:135; KV 1897:151.

45 GB 28-5-1905 no. 4, Bijker et al. 1908:63.

$4^{6} \quad$ Respectively, Soerabaijasche Ziekenverpleging (KV 1898:93) and the Semarangsche Ziekenverpleging; Vereeniging voor Ziekenverpleging ter Oostkust van Sumatra (Vereenigingen 1921:541).

$47 \quad$ Extracten begrooting 1912 1911:10.
} 


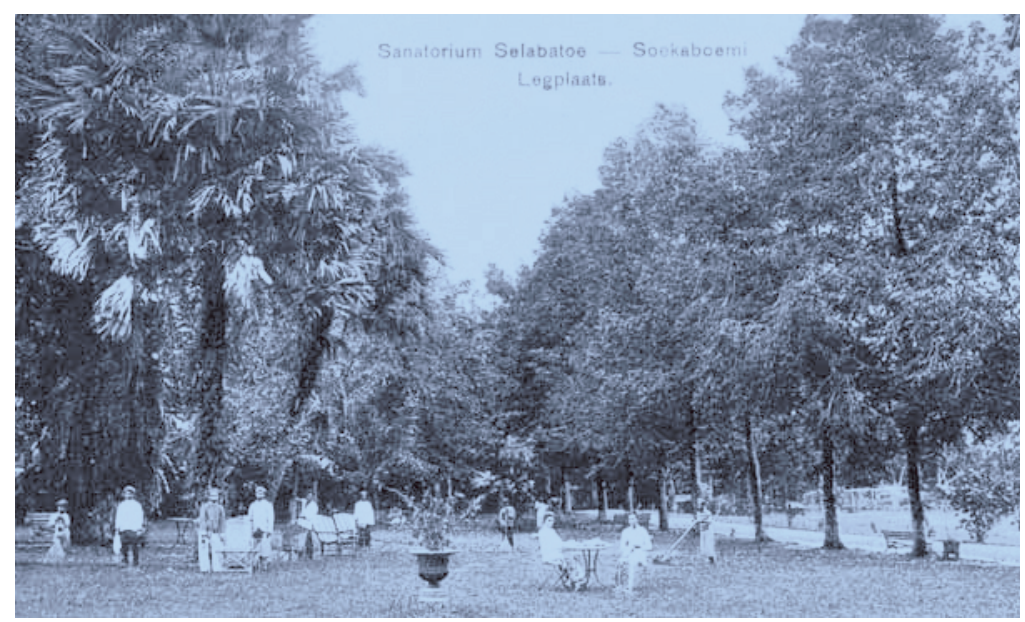

Sanatorium at Selabatu, Sukabumi (postcard from author's collection)

were killed. It was the only hospital in a region with 500,000 inhabitants. Soon Kohlbrugge (1910) and his helpers, whom he trained himself, were treating 6000-8000 patients per year.

\section{FIGURES}

In 1900 there were 110 government and 25 private health care facilities on Java. The government facilities consisted of military (17), native (59), leprosy (3), civil hospitals (10, including the former municipal clinics) and institutions for prostitutes (21). The last were abolished in 1911, along with the inspection of prostitutes. The private institutions could be classified into sanatoria (11), missionary hospitals (6), company hospitals (3) and leprosy clinics (5) ( $K V$ 1902:appendix R). At the end of 1916 there were around 50 private hospitals, ${ }^{48}$ a doubling in 16 years. This illustrates the government policy of turning the management of hospitals over to private initiatives. 
RULES OF THE GAME

The socio-cultural and socio-economic factors influencing the medical market around 1850 - here called rules of the game - remained in force in 1915.

\section{ADAT AND RELIGION}

Norms and values from adat and religion still determined the consumers' behaviour on the medical market. Javanese, convinced of the indivisible nature of the human body, were against surgery on principle. Kohlbrugge (1917:9-10) recommended giving the amputated body part back to the patient because in their animistic belief it was improper 'to leave it in the surgeon's possession'. The fear of the scalpel often faded after someone else had been successfully treated with surgery. 'It is typical of the Javanese that they must first have or know of an example of what the consequences of the surgery are before exposing themselves to the operation,' according to a native eye doctor who conducted Snellen operations under the supervision of the civil physician (Westhoff 1906:11-2). In this operation, eyelids that had turned inward were restored to their proper position.

Sometimes European physicians made use of the population's religious concepts to introduce certain measures. A nice example is provided by the cholera vaccination in Tasikmalaya (Priangan) in the beginning of the twentieth century. When cases of cholera were observed, the physician, A.J.G.J.P. Bakker, decided to vaccinate the population. He paid a call to the patih and the assistant-resident and asked them to assemble the people from the village the following morning. Before he started vaccinating, he addressed the crowd in Sundanese: the devil had sent the bad cholera spirits. Allah 'sent wise people, whom he had taught methods to expel the spirits'. The inhabitants were advised to drink only boiled water because 'the devils causing cholera lived in the water and could not survive boiling' (Bakker 1911:1-6). Religion was also abused: around 1920 German missionaries were thwarted by the Muslim population in the Moluccas. The inhabitants spread the rumour that their medicines contained pork (which is forbidden by Islam) (Heynneman 2002:127). In a village in the district of Kendal (Semarang), research into malaria had to be stopped because of opposition from 
the population who had been told that they would be converted to Christianity. ${ }^{49}$

Sources around 1900 reported increased aversion among native women to male assistants during labour compared with $1850 .{ }^{50}$ For difficult deliveries a European physician or dokter djawa was probably called in more regularly. Native women also had a general aversion to male physicians. During a cholera epidemic in Semarang in 1911, it was arranged for native women to be vaccinated with the cholera serum by their husbands while being supervised by a dokter djawa. ${ }^{51}$ There was also resistance to hospitals in which men, too, were nursed. That is why Raden Adjeng Amirati, a daughter of Pangeran Adipati Ario Pakoe Alam VI, ruler of Yogyakarta, hoped for a hospital for women with female doctors. ${ }^{52}$

The government did not want female government physicians because they would not want to inspect coolies. N. Stokvis-Cohen Stuart (1913:5) considered this unfair: there were enough tasks for a female doctor, even if only examining female coolies. Apparently, the government had no difficulty with female coolies being inspected by male doctors, only with female doctors inspecting male coolies.

\section{CLASSIFICATION IN RACES}

The legal classification of the population into three categories (Europeans, Foreign Orientals and Natives) remained in force until the end of the colonial period. Just like in 1850, sufferers in this period sometimes called on medical assistance from another population group. In his memoirs Madé Djelantik (2001:104), a Western-trained Balinese doctor, described how in his secondary school period he had to pick up the Chinese family doctor Liem at night on his bicycle for his seriously ill European landlady, the wife of a teacher, where he was lodging in Malang around 1930. According to Opheffer, pseudonym of the resident of Rembang, G.L. Gonggrijp, (assistant)-residents' wives would allow themselves to

49 Genees- en Verloskundige hulp in Nederlandsch-Indië 1910:51.

$5^{\circ} \quad$ The Indies government in 1890, Historisch overzicht 1898:55; Soewardjo 1896:47-8; head of the Medical Service in 1902, Bijker et al. 1908:270; Boeka 1904:1009; the residents in response to the survey in 1904, Bijker et al. 1908:271; Lumentut et al. 1910:11-2; respondents in Onderzoek mindere welvaart 1911:90; Djarisah 1914:19.

$5^{1} \quad$ Het Nieuws van den Dag voor Nederlandsch-Indï 26-6-1911, p 6.

$5^{2} \quad$ Onderzoek mindere welvaart 1914:appendix 5. 
be assisted during delivery by a dukun bayi when they had no money. ${ }^{53}$ Kohlbrugge worked in 1891-1898 at the sanatorium in Tosari and also had a private practice there. He was pleased with his 'obedient and grateful' Chinese patients; they paid on time and even sometimes gave a bonus (Kohlbrugge 1917:4-8).

In his book Het leven in Nederlandsch-Indië (Life in the Netherlands Indies, 1900) Bas Veth (1900:133) described the married life of Karel, a 'real' Dutchman, and Dora, the Indo-European daughter of an assistant-resident: 'Dora, an Indies child, venerated the dukun (female native doctor, skilled at this and that), who was repeatedly consulted by her mother about everything to do with the intimate life of women'. When Dora was newly married, the dukun visited her regularly, to the annoyance of her husband who considered every dukun a charlatan. When Karel was ill, the European physician was called. During her pregnancy Dora was monitored by the European physician, although she preferred a dukun's help (B. Veth 1900:133-7). One married couple thus made use of both a European and a native doctor. Probably the husband preferred a European physician because he was a newcomer, and the IndoEuropean wife preferred a dukun, as had her mother.

\section{HEALTH POLICY}

It took a long time before the government felt responsible for the health of the natives. The director of Education, Religion and Industry, P.H. van der Kemp, issued a circular in 1890 to the regional administrators to let them know that the government's involvement with the health of the natives did not extend further than providing assistance during epidemics and acute endemic diseases. The medicines given by the government to controleurs were meant to be used only in epidemics. ${ }^{54}$

This attitude changed under the influence of the ethical policy. The government became involved from that point on with the well-being of the native population. Despite the fierce debates about improving midwifery assistance in the Indies, the government decided to give priority to general medical assistance. This resulted in the expansion of the dokter djawa school and new tasks being assigned to European physicians. In 1900 the civil physicians were requested in a circular from the director

53 Opheffer 1913:69. Gouda (1995:132) called Gonggrijp a confirmed ethicist.
${ }_{54}$ Circular 6-10-1890 no. 9592, KV 1891:134. 
of Education, Religion and Industry, J.H. Abendanon, to open an outpatient clinic for natives in their place of posting; a year later this was expanded to places in the surrounding area. ${ }^{55}$ Because the physicians saw patients at the outpatient clinics who really needed to be admitted for intensive care, in 1901 the native hospitals were opened to all natives and not just forced labourers, prostitutes and mentally ill patients. ${ }^{56} \mathrm{In}$ 1902 Abendanon proposed making native civil servants with a monthly salary of less than $f 150$ eligible for free medical treatment, like their European colleagues. ${ }^{57}$ Due to the shortage of doctors, this regulation could not be implemented until 1906. The group of eligible claimants was thus expanded enormously: on Java it encompassed 81,500 natives and 20,000 Europeans (Bijker et al. 1908:46). There was one difference: European civil servants were eligible for free medical and midwifery assistance, native civil servants only for medical assistance. ${ }^{58}$ The government probably handled this on pragmatic grounds, frugality or both, assuming that the wives of native civil servants would prefer a dukun bayi to Western assistance.

The European physicians unleashed a storm of criticism against the measures because they considered it as adding to their duties. The Bond van Geneesheeren in Nederlandsch-Indië objected to the increase in tasks. ${ }^{59}$ Criticism of the contents of the outpatient clinic proposal came from Kohlbrugge (1904:9), who called it an idea hatched under office lamps. However, sometimes government policy led to a reduction in tasks, such as abolishing the inspection of prostitutes in 1911. The inspections took a lot of time for the European and native doctors and made them and Western medicine unpopular among the population (Bijker et al. 1908:105-6). According to the reorganization Commission, in 1908 there were more institutes for sick prostitutes than native hospitals (Bijker et al. 1908:96). This is not supported by the figures given above, but it is clear that abolishing the inspections created a great deal of space in the hospitals.

55 Circulars 19-10-1900 and 26-1-1901, Kohlbrugge 1904:3; according to Bijker et al. 1908:119 it concerned circular 28-6-1902 no. 12408.

$5^{6} \quad$ GB 25-4-1901 and 6-6-1902, KV 1901:83.

57 Circular from the director of Education, Religion and Industry 7-11-1902 no. 19530, Schülein 1903:1.

$5^{8} \quad$ GB 5-4-1906 no. 65 and no. 66, Ind. Stb. 1906 no. 213 and no. 214.

59 Deye 1902:11-29; W.J. van Gorkom 1904. 
As tasks in the Civil Medical Service were being increased, the need for doctors rose proportionally. To reduce the shortage, the capacity of STOVIA was expanded and new courses created. Kohlbrugge, a civil physician in Sidoarjo (Surabaya), started training assistant-doctors at the beginning of the twentieth century. ${ }^{60}$ Then he submitted a request to the government for an official course for which the students would receive an allowance of $f 15$ per month followed by a salary of $f 30$ per month after obtaining their diplomas. The training physician would receive $f 25$ per year for each candidate. At the end of 1902, a trial of this course was initiated. ${ }^{61}$ Aside from Kohlbrugge (1904:19-22), the civil physician in Kudus, the missionary doctor in Salatiga (both in Semarang) and one in Mojowarno took advantage of this training option (see also Duymaer van Twist 1911:10). This course and the dokter djawa course at the start in 1851 were nearly identical.

Around 1900, the director of the Institute for the Blind in Bandung, C.H.A. Westhoff, opened an outpatient eye clinic where poor patients could be treated for free. He was soon able to interest the government in his initiative. It began with a subsidy in 1901 (KV 1902:207); a year later he was given permission to set up a course to train eye doctors. It started in January 1903, lasted half a year and had room for 10 teenage boys, who received an allowance of $f 10$ per month. ${ }^{62}$ The Department of Education, Religion and Industry specified the competence and obligations of these dukun mata in a regulation (Bijblad 6002). The title dukun mata is curious because it concerns teenagers educated in a Western course - even if brief. It was difficult to find students who met the admissions criterion of being fluent in Dutch (Kohlbrugge 1904:18). The graduates earned $f 30$ per month (Van Kol 1903:583). Westhoff (1906:13) trained a total of 20 dukun mata between January 1903 and the end of 1905, who were assigned after graduation to various residencies. The short duration was criticized (Van Effen 1905:37-48) as were the costs of this course, which could be better used for other purposes (Kohlbrugge 1904:18).

The level of nursing was low. In the military hospitals the nursing personnel consisted of the attendants (soldiers), occasionally referred to

\footnotetext{
6o Verslagen Indisch Genootschap 1907-8:190 (meeting 12-2-1907).

61 GB 22-12-1902 no. 8, KV 1903:205.

$62 \quad$ GB 17-9-1902 no. 27, KV 1903:205.
} 
as 'hospital hyenas', hospital orderlies (corporals) and the medics (sergeant-majors) (Kerkhoff 1989:17). In the municipal clinic in Semarang, the nursing was done by the orderlies and soldiers' wives/concubines. ${ }^{63}$ The head of the Medical Service, J. Haga, mentioned in a memorandum in 1904 that many nurses were 'coolies picked up off the street and babus [female servants] who steal from the Government'. ${ }^{64}$ The situation started improving only at the start of the twentieth century. Mantri-nurses (male and female) were trained from that point on by hospital physicians, who were paid a bonus for this (Geneeskundige Dienst 1917:764). In addition, a number of private hospitals trained nursing personnel for their own institutions. The standard admissions criterion was being literate, which meant that in the beginning only men were admitted. The bad reputation of the municipal clinics, where the students would work after their course, did not help encourage the recruitment of female applicants (Sciortino 1996:96).

Of course, the reorganization Commission commented on the new courses. It regretted the fact that the government's advisors who had approved these courses - probably Abendanon was meant - did not know enough about the history of the medical sector in the Netherlands. They were referring to the different types of physicians in the Netherlands before 1865. The Commission was fiercely opposed to continuing the assistant-doctor and dukun mata courses. ${ }^{65}$ Its recommendation was followed, and both courses were cancelled. ${ }^{66}$ Given the great need for nursing personnel, the reorganization Commission felt that a new course would have to be energetically taken up (Bijker et al. 1908:28-9, 97). The course to train mantri-nurses (male and female) was polished up: a maximum of 100 students, who had completed a public primary school of the second class, could be trained in government or private hospitals by physicians, who would receive a bonus of $f 500$ for each successful graduate. During the three-year course, the students received an allowance of $f$ 10-12 per month, and after their course a monthly salary of $f 25$ with five increases of $f 5$ every three years. ${ }^{67}$ If they left government service

\footnotetext{
$63 \quad$ V.L., 'Inlandsch ziekenpersoneel', Bulletin van den Bond van Geneesheren in Ned.-Indïe 1911:9-15.

$6_{4}$ Memorandum 18-11-1904, Bijker et al. 1908:96.

$6_{5} \quad$ Bijker et al. 1908:28-9, 97. Saeban, a dokter djawa involved with the dukun mata course, vigorously defended it - unfortunately without success - in the Preangerbode; Het Nieuwes van den Dag voor NederlandschIndië dated 18-4-1910, p 2 copied his report with approval.

$66 \quad$ Extracten begrooting 1912 1911:14.

${ }_{67} \quad$ GB 16-1-1912 no. 98, Ind. Stb. 1912 no. 87.
} 
within five years after completing the course, they had to pay back their allowance and the bonus paid to the trainer (Inlandsch verplegingspersoneel 1911:6-8). The government had apparently learned from its experience with the native doctors.

Implementing these plans did not solve all of the problems, however, as was apparent from the Nota betreffende de noodzakelijkheid van verbetering van de ziekenzorg voor Favaansche vrouwen (Memorandum on the need to improve health care for Javanese women), addressed by N. Stokvis-Cohen Stuart in 1914 to the governor-general. In her posting at Semarang, there was little interest in the nurses' course but considerable interest in the midwives' course. She explained that the profession of midwife garnered more respect and better financial prospects. Mrs. Stokvis proposed making the nurses' course more attractive by offering the best students the possibility of subsequently taking the midwives' course. In addition, a boarding school would have to be associated with the course, and European nurses would have to teach it. She rejected the proposed mandatory governmental employment because it would interfere with the wedding plans of young Javanese women (Stokvis-Cohen Stuart 1914:114). She probably hoped to raise the status of the course by employing European nurses. They enjoyed a high esteem in the Indies - just like in the Netherlands. European nurses travelled from the Netherlands to the Indies first class 'taking into account her [their] social standing of women belonging to the civilized class' (Ind. Stb. 1898 no. 104).

\section{FIGHTING EPIDEMICS}

The fear of an epidemic persisted. At the end of the nineteenth century, a series of rules, the quarantine regulations, were prepared against the transmission of contagious diseases from boats in port. ${ }^{68}$ Sanitary measures were introduced onboard ships and in Jeddah to benefit the pilgrims (Peverelli 1947:22). In the description of the duties of the independent Civil Medical Service, fighting epidemics was the priority (Geneeskundige Dienst 1917:763).

During an epidemic there was usually a shortage of doctors, and more had to be sent to the afflicted region. In addition, final-year students from STOVIA were called on; eight were absolved from sitting

\footnotetext{
68 Ind. Stb. 1871 no. 109; KV 1892:119; Ind. Stb. 1892 no. 44 and no. 45; Ind. Stb. 1897 no. 124; Ind. Stb. 1898 no. 329; KV 1898:89.
} 
their final exam in recompense in 1911. Laypeople, called gecommitteerden, were employed; they were natives who could prescribe medicines and supervise the observance of hygienic measures in the village. This happened in Bagelen and in Majalengka (Cirebon) in 1882, in Banten in 1884 and in Demak (Semarang) in 1889.69 To ensure that the medicines were being taken properly, patients whose condition allowed it were required to take their free quinine personally in front of a civil servant or dokter djawa in 1876 during the fever epidemic in Blora (Rembang) (Luchtmans 1876:334). Occasionally, government officials acted harshly. Victims were brutally dragged away, their household possessions burned or sometimes unnecessarily sprayed with creoline (a disinfectant). This caused the natives to offer resistance, even to the extent of killing the disinfectors (Degeller 1910b:6-9).

The recommendations of the dokter djawa and the gecommitteerden to keep home and yard clean during epidemics, to boil water and cover food formed the first attempts to introduce Western ideas about hygiene. The effect was probably marginal. A more important element was the improvement in the drinking water supply by boring artesian wells in the 1880s and 1890s in many towns and smaller locations (Gooszen 1994:308).

The epidemic diseases were malaria, smallpox, beriberi, cholera and plague. The last two in particular terrified the population. Cholera claimed many lives in a short time. The first municipal physician in Semarang, H.G.K.Th. de Ruijter, reported on the unexpected cholera outbreak in 1864: 'The Javanese consider it an evil spirit or devil, bringing death to thousands, and if we want to envisage this concept symbolically, then they are right; this is a suitable image expressing the malicious nature of the disease very well.' The Semarang municipal physician administered the standard cholera mixture. ${ }^{70}$ Kohlbrugge did not want to distribute this cholera drink because it was ineffective. Western medicine would no longer be respected by the population as a result. He had a brochure prepared in Javanese in which he took advantage of the Javanese belief that the cholera spirit lived in the water and could only be killed by fire. ${ }^{71}$ Therefore, he advised boiling the water. His recommendation was successful: people understood the idea, carried it out, and cholera

\footnotetext{
$69 \quad$ KV 1883:113-4; KV 1884:106; KV 1890:120.

$7^{\circ} \quad$ 'Verslag der cholera-epidemie te Semarang gedurende het jaar 1864', Archief Schoute Semarang.

${ }_{71} \quad$ See A.J.C.J.P. Bakker's approach in Tasikmalaya, Bakker 1911:1-6.
} 
disappeared without medicines or carbolic being required (Kohlbrugge 1907:192). Businessman and author Bas Veth (1900:242-3) described a cholera outbreak in his own graphic way:

The cholera raged as an epidemic. The natives in their compounds died like rats and mice. In the Chinese camp something was wrong, too; every day five, six, ten cases. But the cholera had spared the European population of the region. (...) Then suddenly: a shock, fear running through the European community. Could you believe it: - Mr. A. has cholera. The first European to be afflicted by this horrible disease. (...) The body of the cholera victim was left lying there, and the families living nearby the deceased complained to the assistant-resident for the police, whining out of fear of cholera, claiming that the body had already begun to stink and the stench was driving them out of their houses. A letter was written to the warden of the prison: 'Arrange for several detainees to be there at 8 o'clock to bury the body of Mr. A.'.

It is typical of Veth and his disdain for the Indies that he emphasized that the Europeans considered it more awful that one European died than did many natives and Chinese. ${ }^{72}$

Despite all the precautionary measures there was a plague epidemic in 1911, which has been described in detail. ${ }^{73}$ The large-scale campaign at the start of the outbreak produced great suspicion among the local population: 'The locals call the disinfection procedure an evil magic exercised by the Dutch'. ${ }^{74}$ In some places the resistance against a spleen biopsy, to determine whether the plague was the cause of death, was so great that the mantri-information officials were stoned (Peverelli 1947:12). Attempts were also made to combat the plague with recommendations to improve the houses to prevent the rats nesting there. Hadjiwibowo, officer with the Royal Dutch Marine, described how his father worked as supervisor of housing improvement, part of the Department of Health. He had to ensure that bamboo poles were replaced by teak beams, as rats tended to nest in the hollow bamboo. His father was frequently transferred: he 'moved so to speak with the spread of the plague from east to west' (Beynon 1995:72).

\footnotetext{
$7^{2}$ With his grumbling, Veth was an extreme racist even according to the standards of 1900, Bosma 2010:205.

73 Mededeelingen Burgerlijken Geneeskundigen Dienst 1912.

74 Houben 1996:77. Unfortunately, Houben did not give a source.
} 
Formally, the government did not exert coercion to implement measures aimed at improving the health of the natives. ${ }^{75}$ For example, the population did not have to call in the native midwives if they did not want to. Nevertheless, rumours persisted that coercion was exerted, especially with the smallpox vaccination. Some Chinese administrators refused to issue passes to non-vaccinated Chinese, which they needed to trade outside the boundaries of their residency (Kohlbrugge 1903:27). Kohlbrugge stated that everyone in his district who did not turn up to be vaccinated was fined 1 or 2 guilders or sentenced to forced labour. In Banten the penalty was a maximum of 5 guilders. One native head told Kohlbrugge that if the natives had been aware of the official rules, no one would have let themselves be vaccinated (Kohlbrugge 1903:12-4). Vaccination took an entire working day and thus wages; therefore, they sometimes sent a substitute whom they paid. Young women in particular often sought replacements: '[T] hey refused to expose themselves in public, also they feel that their attractiveness could lead to trouble or their husband's jealousy could be aroused: our civil servants are not eunuchs' (Kohlbrugge 1903:15-6). Despite the extensive cover provided by the smallpox vaccination, epidemics still broke out regularly.

The rulers in the Principalities also had a certain health policy. They employed their own vaccinators ( $K V$ 1886:107); and one of them also had a native midwife. In addition, they maintained various institutes, sometimes with financial support from the inhabitants, including one for lepers (KV 1882:117; KV 1891:135). Prince Mangkunegoro VII established a hospital in Surakarta and several outpatient clinics outside the town (Van der Woerdt 2004:68).

\section{CONCLUDING REMARKS}

In comparison with the medical market around 1850, the position of the dukun in the native market of medical goods and services was still strong in 1915. Another constant element was the natives' resistance to Western medicine. From the survey conducted at the beginning of the twentieth century by the prosperity Committee, it seems that the

75 In the Cultivation System there was coercion exerted, the corvée labour demands. 
population preferred to be treated by a dukun when ill and to take native medicines rather than European (Onderzoek mindere welvaart 1911:88). For the millions of inhabitants, there was only a handful of Western-trained doctors. In addition, the fee paid to a Western-trained native doctor was almost always higher than that charged by a dukun, and often there were additional travel expenses because of the distances involved. The dukun's insinuations also had an effect. Kohlbrugge gave as an explanation that Western physicians did not speak the local languages and did not exert themselves to win the trust of the natives or understand their concepts of disease. There was also their fear of the scalpel, with which Western physicians were associated, even by educated natives, according to $\mathrm{J}$. Kwast, civil physician in Krawang:

\begin{abstract}
A highly educated, very European-oriented native head informed me that the fatally ill patients were finished off by poison in the hospital. As such stories are spread by the dukun, naturally the villagers regard European assistance with distrust. Then people believe in general that a European physician stands there with a scalpel ready in his hands all day long and starts cutting immediately without bothering to ask if the patient approves. (Onderzoek mindere welvaart 1911:91.)
\end{abstract}

Another persistent mindset was the negative attitude of Western physicians towards the dukun and indigenous medicine. The independent Civil Medical Service clearly understood that the dukun was a formidable competitor. The native doctors were ordered - at least in Central Java - to combat the dukun on the one hand, while learning as much as possible about their treatment methods on the other.

Something else that had remained the same since 1850 was the imperfect separation between the population groups: sometimes the natives called in the assistance of a sinse, and the (Indo-)Europeans consulted a dukun. There are indications that in this period the reciprocal competition increased. The Chinese kept their formulas secret or would sell them only for large sums of money to physicians from another population group. It caused friction that the government regulated the European physicians and medicines, but not the Chinese and native ones, which made the competition 'unfair'. The European physicians also competed with each other: 'Let us not forget that on Java the competition among the doctors grows daily' (W.J. van Gorkom 1904:11). This referred to the competition 
between physicians with a lucrative practice at a private company and those who had to work hard for the government, on whom 'exceptional demands of sacrifice' were imposed, keeping them from establishing a private practice. Many European physicians also regarded with envy the popularity of self-help guides written by Indo-European ladies and the use of midwifery instruments by European midwives. As people who treated themselves did not make use of the medical market, the popularity of self-help guides did form a serious threat for some providers.

Despite all the opposition, at the beginning of the twentieth century in an absolute sense Western medical facilities were more frequently used by natives than in 1850 . As a result of the ethical policy, more outpatient clinics and native hospitals were available. The missionary hospitals were popular, especially among Christian natives. The Petronella Hospital of the missions was a model for other hospitals. The government increasingly left the management of the hospitals and the training of nursing personnel to private initiatives. 